\title{
“UNITING FOR PEACE”: DOES IT STILL SERVE ANY USEFUL PURPOSE?
}

\author{
Larry D. Johnson*
}

During the past several years, vetoes have been cast in the UN Security Council to block draft resolutions aimed at addressing the crises in Syria and Ukraine. Concerning Syria, Russia and China have vetoed three resolutions (the votes were 9-2-4 on October 4, 2011, 13-2-0 on February 4, 2012, and 11-2-2 on July 19, 2012). Concerning Ukraine, Russia vetoed a resolution just recently (the vote was 13-1-1 on March 15, 2014). The same question that arose in 1950 has thus arisen again today: can the General Assembly do anything when the Council is blocked because of a permanent member casting a veto? The answer is "yes." But the reason is not because of the Assembly's resolution 377A(V) of November 3, 1950 ("Uniting for Peace"1), even though advocates of Assembly action frequently invoke it. Indeed, this resolution is for the most part no longer needed to provide a basis for Assembly "collective measures" recommendations when a veto proscribes the Council's adoption of such measures. Moreover, the resolution does not provide a basis or justification for the use of force that would not be justified on other grounds, such as self-defense.

\section{What is the Uniting for Peace resolution?}

The resolution entitled "Uniting for Peace" was adopted, as a whole, by the General Assembly at its 302nd plenary meeting on November 3, 1950 by a non-recorded vote of fifty-two in favor, five against, and two abstentions.

The key provision is paragraph 1 of section A of resolution $377 \mathrm{~A}(\mathrm{~V})$ :

The General Assembly ...

1. Resolves that if the Security Council, because of lack of unanimity of the permanent members, fails to exercise its primary responsibility for the maintenance of international peace and security in any case where there appears to be a threat to the peace, breach of the peace, or act of aggression, the General Assembly shall consider the matter immediately with a view to making appropriate recommendations to Members for collective measures, including in the case of a breach of the peace or act of aggression the use of armed force when necessary, to maintain or restore international peace and security. If not in session at the time, the General Assembly may meet in emergency special session within twenty-four hours of the request therefor. Such emergency special session shall be called if requested by the Security Council on the vote of any seven [now nine] members, or by a majority of the Members of the United Nations.

* Adjunct Professor at the Columbia Law School. He served at the UN Headquarters as the Assistant-Secretary-General for Legal Affairs from 2006-2008 (Deputy Legal Counsel of the UN). He formerly served as the Legal Adviser of the International Atomic Energy Agency in Vienna (19972001) and as Chef de Cabinet, Office of the President of the International Criminal Tribunal for the former Yugoslavia in The Hague (2003-2005).

Originally published online 15 July 2014.

${ }^{1}$ Uniting for Peace, GA Res. 377A(V) (Nov. 3, 1950).

ASIL and Larry D. Johnson (C) 2014 
This dense text requires careful dissection to ascertain what it requires and how it operates. First, it is necessary to have had a Security Council resolution fail to be adopted, not because of failure to achieve the required majority of nine "yes" votes, but rather because a permanent member cast a negative vote which prevented the adoption of a resolution which would have otherwise been adopted (i.e., a veto "trumped" the required majority). The language in Uniting for Peace refers to this in the following terms: "if the Security Council ... fails to exercise its primary responsibility" because of lack of unanimity of the permanent members. It was pointed out by the Soviets in 1950 that that language is per se prejudicial against the permanent member casting the negative vote. It is doubtful that any permanent member would consider its casting a veto as preventing the Council from exercising its primary responsibility; just the reverse. The negative vote saved the Council from taking what would have been an illegal, unwise, precipitous, or erroneous decision. Presumably whenever a permanent member casts a veto it does so because it believes it must in the light of its own national interests and in defense of the purposes and principles of the Organization. It is simply exercising a right given to it under the UN Charter precisely to prevent the adoption of a proposal. In cases in which Uniting for Peace has been invoked following a veto, the Soviets vetoed five times, the U.S. in two cases, France/United Kingdom/U.S. together in two cases, and France/United Kingdom together in one case.

Second, one of three events must have arisen: threat to the peace, breach of the peace, or act of aggression ("in any case where there appears to be a ..."). Here the Assembly would be assessing whether a situation appears to constitute one of the three situations that the Council must determine exists in order for it to operate within the ambit of Chapter VII ${ }^{2}$ of the Charter (Article 39). In Uniting for Peace, as the Council has been blocked by a veto, it is the Assembly that makes the judgment whether it "appears" that one of the three situations exists.

If both of these requirements are met, the Assembly "shall" consider the matter immediately with a view to making appropriate recommendations to Members for collective measures in order to maintain or restore international peace and security. Thus, if acting under Uniting for Peace, the Assembly would not be purporting to issue binding decisions or orders to any or all Member States requiring them to take collective measures. States would be free to follow those recommendations or not. There is no encroaching on the Council's exclusive power to impose coercive measures on a State or States or to decide that Governments are required to take certain measures under Chapter VII.

\section{What about the use of force?}

The most controversial aspect of Uniting for Peace is the following additional phrase after the proviso that the Assembly shall consider making recommendations to Members for collective measures: "including in the case of a breach of the peace or act of aggression, the use of armed force when necessary ...." So a recommendation for collective measures could include a recommendation that States use armed force, but only in the case of a breach of the peace or an act of aggression and when necessary, not in the case of a "mere" threat to the peace.

\section{When could the Assembly meet?}

The text provides for procedures to follow in the event the Assembly is "not in session." By those procedures, an emergency special session of the Assembly is convened. This was very important in the early days of the Organization when the Assembly met from mid-September to mid-December and then adjourned

${ }^{2} \underline{\text { UN Charter art. } 39 .}$ 
until its next session began the following September, with delegates returning home and leaving only a skeleton staff in missions at Headquarters.

There have been ten emergency special sessions since the adoption of Uniting for Peace. On one occasion, Uniting for Peace was used to bring a matter before the Assembly when it was in regular session (East Pakistan/Bangladesh19713) and hence an emergency special session was not convened. On the other hand, the tenth emergency special session on Palestine $e^{4}$ began in 1997 and technically can still be resumed. It was decided for political reasons to convene an emergency special session rather than using the regular session of the Assembly which was then meeting.

Today and for the past twenty years or so, the Assembly meets "year around" and only adjourns in midSeptember the day before the new session begins. There is virtually no break between sessions other than a few hours. Thus there is no longer a need to go through the procedural hurdles of calling for an "emergency special session" unless there is a desire to make a political point that the issue should not be treated as if it were business as usual, but as a particularly alarming or dangerous situation which merits separate treatment by the Assembly.

\section{Why was this resolution adopted?}

The resolution stems ${ }^{5}$ from the blockage of action in the Council by Soviet vetoes during the Korean War. It may be recalled that in June of 1950 armed forces of North Korea entered South Korea and the Security Council determined that the South had been the subject of an "armed attack" by forces from the North, constituting a breach of the peace. By resolution 83 of June 27, 1950, ${ }^{6}$ the Council recommended "that the Members of the United Nations furnish such assistance to the Republic of Korea as necessary to repel the armed attack and to restore international peace and security in the area." A few days later, the Council welcomed the prompt and vigorous support that Governments and peoples had given to assist the South "in defending itself against armed attack and thus to restore international peace and security in the area" (emphasis added).

Legally, there has long been doctrinal argument over whether this was a case of the Council supporting a State exercising its inherent right of individual and collective self-defense under Article 51 or whether this was the first time the Council took "enforcement measures" 8 under Chapter VII, since it authorized the use of armed force against a state and referred to restoring peace and security in the area. What is clear is that Member States were not ordered to provide troops or to take any measures decided upon by the Council under Chapter VII; the Council did not require States to take any measures or action. The Council could not follow the design set forth in the Charter for a collective security system that the Council would initiate, with itself and its Military Staff Committee taking "such action by air, sea or land forces as may be necessary,", members having made available to the Council armed forces "on its call" 10 pursuant to agreements concluded between members and the Council. No Article 43 agreements have ever been concluded. The Council had no

${ }^{3}$ UN Rep. of the Security Council, Security Council Deadlocks and Uniting for Peace: An Abridged History (Oct. 2013).

${ }^{4}$ UN GA, Tenth Emergency Special Session: Illegal Israeli actions in occupied East Jerusalem and the rest of the Occupied Palestinian Territory (Apr. 1997-Jan. 2009).

${ }^{5}$ Christian Tomuschat, Uniting for Peace, UN Audiovisual Library of INTERNATIONAL LAW (2008).

${ }^{6} \underline{\text { SC Res. } 83}$ (June 27, 1950).

7 SC Res. 84 (July 7, 1950).

${ }^{8}$ UN Charter art. 50.

${ }^{9}$ UN Charter art. 42.

${ }^{10}$ UN Charter art. 43. 
UN army “on its call." In 1950, the Council used what it must have considered to be its next best option: a recommendation that States provide South Korea with such assistance as necessary to repel the armed attack. Today, the Council's practice followed since the early 1990s is to "authorize" certain States and/or organizations "to use all necessary means" to enforce a resolution or obtain a desired objective, it being understood that that phrase includes the use of coercive armed force if necessary.

Why were these two Council resolutions not vetoed by the USSR? It was absent in protest of the continued presence in the Security Council of the Chiang Kai-shek regime as the representative of China, a permanent member, despite the military victory of the Chinese Communists on the mainland the year before. The Soviet Government assumed that without one of the permanent members, the Council could take no substantive decisions however, it misjudged. Once it saw that decisions were being taken in its absence, its representatives returned and began vetoing resolutions dealing with the Korean crisis. It was in this context that the United States and those assisting South Korea were faced with the question of how to continue UN oversight of the Korean crisis without the Council. Thus was born the Uniting for Peace resolution, proposed by U.S. Secretary of State Dean Acheson to enable the Assembly to consider and make recommendations on matters which the Council had been unable to act upon due to Soviet vetoes.

What issues did Uniting for Peace address and how has the practice evolved?

At the time it was adopted, the sponsors of Uniting for Peace intended the resolution to solve or address three main issues:

1. How to get the Assembly back in session quickly when an international peace and security crisis arises outside the Assembly's regular session time frame?

As indicated above, this problem has disappeared with the current Assembly practice of being continuously in session throughout the year. There is no longer any need to use Uniting for Peace for this purpose, although States may propose emergency special sessions for political, "high profile" reasons.

2. How can the Assembly make recommendations with regard to a particular dispute or situation threatening international peace and security, despite the text of Article 12 (http:/ / wmw.un.org/en/documents/charter/chaptert.shtml) [10] which bars it from making any recommendations while the Council is exercising its functions in respect of that dispute or situation?

Article 12(1) provides that "while the Security Council is exercising in respect of any dispute or situation the functions assigned to it in the present Charter, the General Assembly shall not make any recommendation with regard to that dispute or situation unless the Security Council so requests." This was a matter of such concern in the early years that items were removed from the Council's agenda when the Assembly wished to discuss them. This practice has fallen by the wayside as the Assembly over the years has discussed items and adopted recommendations on items on the agendas of both bodies. This practice was noted and described by the International Court of Justice (ICJ) in the "Wall Case"11 in 2004 as follows:

[T] he Court notes that there has been an increasing tendency over time for the General Assembly and the Security Council to deal in parallel with the same matter concerning the maintenance of international peace and security. .. . The Court considers that the accepted practice of the General Assembly, as it has evolved, is consistent with Article 12, paragraph 1, of the Charter.

Indeed, the ICJ noted that pursuant to Article $11(2),{ }^{12}$ the Assembly may discuss any questions relating to the maintenance of international peace and security brought before it by various actors and, except as provid2004).

${ }^{11}$ Legal Consequences of the Construction of a Wall in the Occupied Palestinian Territory, Summary of Advisory Opinion (July 9 ,

${ }^{12}$ UN Charter art. 11, para. 2. 
ed by Article 12, may make recommendations with regard to such questions. The ICJ considered that the only action which was exclusively within the domain of the Council was coercive or enforcement action. The important point is that Uniting for Peace is no longer needed in order for the Assembly to discuss matters or adopt resolutions on items also on the agenda of the Council.

It should be noted, however, that pursuant to Article 18,13 Assembly recommendations with respect to the maintenance of international peace and security are considered "important questions" requiring a majority of two-thirds members present and voting for adoption.

3. In what circumstances can the Assembly make recommendations for collective measures, including the use of armed force in the case of a breach of the peace or an act of aggression?

\section{i) Non-use of force collective measures}

First, the matter of the Assembly making recommendations for non-use of (armed) force collective measures should be considered. Such measures may be similar to those found in Article $41^{14}$ which gives a non-exhaustive list of measures that the Council may decide upon to give effect to its decisions and call upon States to apply. These include such matters as severance of diplomatic relations, trade embargoes, economic sanctions, and interruption of means of communication. Even before Uniting for Peace, in 1946, it was the Assembly that called upon member States to recall their accredited diplomats from Franco Spain. ${ }^{15}$

As for resolutions emanating from Uniting for Peace-based sessions, some have dealt with establishing peacekeeping operations (such as UNEF $I^{16}$ in 1956 and ONUC ${ }^{17}$ in 1960). It should be stressed that peacekeeping operations are not enforcement measures or the coercive use of force, as the consent of the territorial sovereign or of the parties concerned have been given (although sometimes such consent is illusory or dissipates). Indeed, when the ICJ in its "Certain Expenses" advisory opinion of $1962^{18}$ examined the legality of the Assembly having set up the UNEF and ONUC peacekeeping operations, it noted that the two operations were not enforcement actions within the "compass" of Chapter VII of the Charter. It stated that the Charter empowered the Assembly by means of recommendations to organize peacekeeping operations, at the request, or with the consent, of the States concerned. Other Uniting for Peace-based sessions have resulted in the Assembly taking a variety of non-use of force measures, ${ }^{19}$ such as: establishing a commission of inquiry (Hungary 1956), calling for the withdrawal of foreign troops from Jordan and Lebanon (1958), calling for the rescission by Israel of unilateral measures in Jerusalem (1967), providing assistance to East Pakistani refugees (1971), calling for the withdrawal of foreign troops from Afghanistan (1980) and for the withdrawal of Israel from territories occupied since 1967 (1980), condemning South Africa for the occupation of Namibia and calling for assistance to the liberation struggle (1981), and requesting an advisory opinion of the ICJ on the legal consequences of the construction of a wall in the occupied Palestinian territory (1997).

13 UN Charter art. 18, para. 2.

14 UN Charter art. 41.

${ }^{15}$ GA Res. 39/1 (Dec. 11, 1946).

16 UN, First United Nations Emergency Force, UNEF I (Nov. 1956-June 1967), Completed Peacekeeping Operations: Middle East (2003).

${ }^{17}$ UN, United Nations Operation in the Congo, ONUC (July 1960-June 1964), Completed Peacekeeping Operations: Republic of the Congo (2001).

${ }^{18}$ Certain Expenses of the United Nations (Article 17, Paragraph 2, of the Charter), Advisory Opinion, 1962 ICJ REP. 151,166 (July 20).

19 See UN Rep. of the Security Council, supra note 3. 
In addition, Uniting for Peace-based sessions have resulted in the adoption of what might be termed "voluntary sanctions," such as the following:

(a) Resolution 1474 (ES-IV) of September 20, 1960:20 the Assembly called upon States "to refrain from the direct and indirect provision of arms or other materials of war and military personnel and other assistance for military purposes in the Congo."

(b) Resolution ES-8/2 of September 14, 1981:21 the Assembly called upon Member States "to render increased and sustained support and material, financial, military and other assistance" to the South West Africa Peoples' Organization "to enable it to intensify its struggle for the liberation of Namibia." It also called upon "the international community to extend, as a matter of urgency, all support and assistance, including military assistance, to the front-line States in order to enable them to defend their sovereignty and territorial integrity against the renewed acts of aggression by South Africa."

(c) Resolution ES-9/1 of February 5, 1982:22 the Assembly called upon Member States "to apply the following measures: (a) to refrain from supplying Israel with any weapons and related equipment and to suspend any military assistance which Israel receives from them ...."

After Uniting for Peace was adopted and without having invoked it, the Assembly has recommended during a regular session "voluntary sanctions," most famously in resolution 41/35F23 of November 10, 1986, entitled "Oil Embargo Against South Africa," by which the Assembly "request[ed] all States concerned, pending a decision by the Security Council, to adopt effective measures and/or legislation to broaden the scope of the oil embargo in order to ensure the complete cessation of the supply and shipment of oil and petroleum products to South Africa and Namibia, whether directly or indirectly." Another resolution ${ }^{24}$ of the same date appealed to States to consider national legislative or other appropriate measures to increase the pressure on the apartheid regime of South Africa and gave examples such as cessation of further investment in, and financial loans to, South Africa. It is of interest to note that this is a case where both Assembly voluntary sanctions and Council-imposed sanctions were in effect at one and the same time, the Council having, under Chapter VII, imposed an arms embargo on South Africa in 1977.

In sum, voluntary collective measures have been recommended by the General Assembly without reference to Uniting for Peace. There is no need to refer to Uniting for Peace in order for the Assembly to recommend non-use of force collective measures.

\section{ii) Use of force collective measures}

It is sometimes thought that Uniting for Peace has been used by the Assembly to recommend or authorize the use of force when the Council has been blocked by the veto, the Assembly substituting itself for the Council to recommend enforcement action. This is incorrect. In practice there are only one or two resolutions that arguably fall within this category, according to Professor Christian Tomuschat. ${ }^{25}$ On February 1, 1951, the Assembly adopted resolution 498(V), by which, repeating the language of Uniting for Peace that because of a veto the Council had failed to exercise its primary responsibility, it called upon "all States and authorities to lend every assistance to the United Nations action in Korea"- "every assistance" arguably being the use of force in order to assist South Korea repel the armed attack.

${ }^{20}$ GA Res. 1474 (ES-IV) (Sept. 20, 1960).

${ }^{21}$ GA Res. ES 8/2 (Sept. 14, 1981).

22 GA Res. ES-9/1 (Feb. 5, 1982).

${ }^{23}$ GA Res. 41/35F (Nov. 10, 1986).

${ }^{24}$ GA Res. $41 / 35$ H (Nov. 10, 1986).

25 See Christian Tomuschat, supra note 5. 
In the Korean case, armed force was already being used in collective self-defense. Uniting for Peace was not used to recommend the use of armed force in the sense of any new enforcement action or coercive measures. In the South African resolution ES-8/2 noted above, again the resolution did not recommend enforcement action, or the use of coercive force against South Africa, but rather called upon the provision of military assistance to States in order for them to defend their sovereignty and territorial integrity against acts of aggression by South Africa. And in both instances, the language used indicates situations in which use of force is recommended by the Assembly in the context of collective self-defense.

Can Uniting for Peace be used to recommend enforcement measures or the use of force in non-self-defense contexts, such as for bumanitarian intervention purposes? Can the Assembly lanfully recommend that States take action that would violate Article $2(4)^{26}$ of the Charter?

The ICJ in the "Certain Expenses" advisory opinion of 1962 noted that under the Charter, it is the Council which is given a power to impose an explicit obligation of compliance and only the Council can require enforcement by coercive action against an aggressor. ${ }^{27}$

But is the problem solved so simply by using Uniting for Peace to have the Assembly make "recommendations to Members for collective measures"? While of course such recommendations are not binding in the sense that Members are not required to take the recommended collective measures, from the standpoint of the "targeted State" there would certainly be effects or consequences. Professor Franck ${ }^{28}$ asks whether under Uniting for Peace the Assembly could call upon States to use force to resist an act of aggression or to stop a government from committing genocide against a minority of its population. While couched as a recommendation, obviously it is more than a recommendation for the State against whom force is being recommended. He concludes by noting that while this was scarcely touched upon during the debate in 1950, both advocates and proponents of Uniting for Peace understood its effect would, in some unspecified instances, be to empower the Assembly to deploy military force. But could the Assembly actually recommend that States use force in violation of Article 2(4) that prohibits the threat or use of force against the territorial integrity or political independence of any State or in any other manner inconsistent with the Purposes of the Charter?

The two hypothetical examples of Professor Franck entail two totally different scenarios: one in which Uniting for Peace would be lawful and the other in which it probably would not. In his first scenario of the Assembly recommending the use of force to resist an act of aggression, it would seemingly fall precisely within the intended ambit of Uniting for Peace: an act of aggression appears to have occurred and collective measures can be recommended by the Assembly if a veto has blocked Council action. But what is recommended is not enforcement or coercive action as such; it is collective self-defense under Article $51^{29}$ of the Charter, which any State or States can exercise in case of armed attack. No Council or Assembly approval is necessary. Thus, in that scenario, the Assembly is simply encouraging or supporting the attacked State to defend itself and recommending that other States come to the collective self-defense of the attacked State. To illustrate, if a veto had blocked a decision by the Council, authorizing the use of all necessary means to force Iraq out of Kuwait in 1991, a Uniting for Peace-type resolution could have been adopted by the Assembly calling on States to assist Kuwait in defending itself and to engage in collective self-defense. As long as the

${ }^{26}$ UN Charter art. 2, para. 4.

27 See Certain Expenses of the United Nations (Article 17, Paragraph 2, of the Charter), Advisory Opinion, 1962 ICJ REP. 151, 163 (July 20).

28 Thomas M. Franck, Recourse to Force: State Action Against Threats and Armed AtTacks (2002).

${ }^{29}$ UN Charter art. 51. 
use of force being recommended by the Assembly can be considered as part of an exercise of self-defense under Article 51 (individual or collective), no violation of Article 2(4) would be involved.

The difficulty arises with regard to his second scenario-stopping a genocidal State from murdering parts of its own population. Here, outside the self-defense context and absent a Security Council Chapter VII use of force authorization, it is difficult to see how an Assembly recommendation that States use force squares with the norm reflected in Article 2(4), although some have suggested this course of action is possible.

In its 2001 report $^{30}$ on "Responsibility to Protect," the Canadian International Commission on Intervention and State Sovereignty, an independent commission of experts, stated that while the Assembly lacked the power to order military action, "a decision by the General Assembly in favour of action, if supported by an overwhelming majority of Member States would provide a high degree of legitimacy for an intervention which subsequently took place, and encourage the Security Council to re-think its position." Seemingly a group of States might receive the Assembly's blessing (for humanitarian intervention or "responsibility to protect" reasons) before engaging in collective action without Security Council approval. This possibility was not endorsed by the UN's High-Level Panel of Experts nor by the Secretary-General.

Moreover, the "responsibility to protect" concept as adopted by the Assembly in the 2005 World Summit Outcome resolution ${ }^{31}$ (resol. 60/1) does not foresee the Assembly recommending that States use coercive force to stop a State from committing genocide against it own population. It states that "we [Heads of State and Government] are prepared to take collective action, in a timely and decisive manner, through the Security Council, in accordance with the Charter, including Chapter VII, on a case-by-case basis and in cooperation with relevant regional organizations as appropriate, should peaceful means be inadequate the national authorities are manifestly failing to protect their populations from genocide, war crimes, ethnic cleansing and crimes against humanity." The Assembly, on the other hand, is to continue consideration of the concept and its implications, bearing in mind the principles of the Charter and international law.

And what of "humanitarian intervention"? This concept has not been approved as such by the Assembly or the Council, nor was it invoked by name in the NATO intervention in Kosovo. The United Kingdom, however, has for some time taken the position that the use of force to avert an overwhelming humanitarian catastrophe has been emerging as an exceptional basis for the use of force, beyond self-defense. It was relied on by the UK in the Kosovo crisis and was the underlying justification ${ }^{32}$ for the No-Fly Zones in Iraq. On August 29, 2013, "guidance"33 was issued by the UK Prime Minister's Office on his government's position regarding the legality of any military action in Syria following the chemical weapons attack in Eastern Damascus. In that guidance, it was said that if action in the Security Council is blocked, "the UK would still be permitted under international law to take exceptional measures in order to alleviate the scale of the overwhelming humanitarian catastrophe in Syria by deterring and disrupting the further use of chemical weapons by the Syrian regime." In its view, such a legal basis is available under the doctrine of humanitarian intervention provided certain conditions are met: i) there is convincing evidence, generally accepted by the international community as a whole, of extreme humanitarian distress on a large scale, requiring immediate and urgent relief; ii) it must be objectively clear that there is no practicable alternative to the use of force if lives are to be saved; and iii) the proposed use of force must be necessary and proportional to the aim of relief of humanitarian need and must be strictly limited in time and scope to this aim (i.e., the minimum necessary to achieve that end and for no other purpose).

\footnotetext{
${ }^{30}$ Rep. of the Int'l Comm'n. on Intervention and State Sovereignty, The Responsibility to Protect (Dec. 2001).

312005 World Summit Outcome, GA Res. 60/1 (Sept. 16, 2005).

32 Letter from the U.K. Attorney General to the U.K. Prime Minister, Iraq: Resolution 1441 (Mar. 7, 2003).

33 U.K. Prime Minister's Office, Policy Paper: Chemical Weapon Use by Syrian Regime: UK Government Legal Position (Aug. 29, 2013).
} 
The UK position dealt with the use of force by one or more States without UN involvement. But could the Assembly adopt a resolution under Uniting for Peace to the same effect, justifying a recommendation to States to use force in order to avert an overwhelming humanitarian catastrophe, such as a State committing genocide on its own citizens? Assuming there was a veto blocking Council action, the Assembly would have to deem that the overwhelming humanitarian catastrophe appears to constitute a breach of the peace. If so, could the Assembly simply state that an emerging doctrine of humanitarian intervention has arisen under international law that would allow the Assembly to recommend that States use coercive force to avert that catastrophe, (i.e., an "up-dating" of Uniting for Peace)? Under what Charter authority would the Assembly make such a recommendation?

Article 2(4) remains the main legal obstacle. The Assembly recommending that States use force outside the self-defense context does not relieve States of their obligations under Article 2(4). The Assembly has no such power to relieve States of their Article 2(4) obligations and never did. The 2001 International Law Commission draft articles ${ }^{34}$ on the responsibility of States for internationally wrongful acts contain six circumstances which preclude the wrongfulness of such acts: consent, self-defense, countermeasures, force majeure, distress, and necessity. Only self-defense provides a clear circumstance which would preclude the wrongfulness of using force by providing that the wrongfulness of an act of a State is precluded if the act constitutes a lawful measure of self-defense taken in conformity with the Charter of the United Nations (article 21 of the draft articles).

As for the other circumstances, article 26 stipulates that none of the circumstances precluding wrongfulness could excuse an act not in conformity with an obligation arising under a peremptory norm of general international law. In 1986, the ICJ noted ${ }^{35}$ in the Nicaragua case that the principle of the non-use of force expressed in Article 2(4) is often referred to by States as a fundamental or cardinal principle of customary international law and was viewed by the ILC in 1966 as having the character of jus cogens.

Thus, the bottom line is that the controversial section of Uniting for Peace referring to an Assembly decision recommending that States use force can only be considered trouble-free and legally well-founded if such recommendations are made in the context of the Assembly calling on Members to support the inherent right of individual or collective self-defense under Article 51. In essence, this is what happened in 1950 in the Council's recommendation that Members furnish such assistance to South Korea as necessary to repel an armed attack and in the follow-up 1951 Assembly resolution calling upon States to lend every assistance to the UN action in Korea.

Politically, it may be assumed that most permanent and some other members would resist proposals to have the Assembly recommend any use of force as a matter of principle. They would prefer to keep decisions regarding the maintenance of peace and security within the purview of the Council as that is its primary responsibility. We have seen in Kosovo that despite the possibility of acquiring Assembly approval for a "humanitarian intervention" operation, NATO and other members preferred to act on their own with no UN cover whatsoever. They might have been concerned about obtaining the necessary two-thirds majority, but perhaps more importantly they might have been more concerned with a "slippery slope" phenomenon, not knowing how the precedent would be used in the future or how States would individually interpret and apply a recommendation to use armed force. States may well hesitate in supporting the Assembly recommending

${ }^{34}$ Int'l Law Comm'n, Responsibility of States for Internationally Wrongful Acts, 53rd Sess., Apr. 23 - June 1, July 2 - Aug. 10, 2001, U.N. Doc. A/56/10; GAOR, 56th Sess. (2001).

35 Case Concerning the Military and Paramilitary Activities in and Against Nicaragua (Nic. v. U.S.), Judgment, 1986 ICJ REP. 14 para. 190 (June 27). 
the use of force in view of the risk of "shifting majorities" targeting certain States (e.g., Israel), resulting in an increased risk of inter-State violence.

\section{Is Uniting for Peace needed today?}

The short answer is "no," or only in limited circumstances.

As indicated above, there is no reason to use Uniting for Peace in order to call emergency special sessions. The Assembly is in session all year around. If States want to use it to highlight a particular emergency or crisis, that is a policy question.

There is no longer any concern that the Assembly cannot consider any dispute or situation that is also before the Council. The ICJ advisory opinion in the "Wall" case disposed of that.

The Assembly has adopted "voluntary sanctions" provisions with and without reference to Uniting for Peace; hence, it is not needed for that purpose.

As regards the Assembly recommending the use of force pursuant to Uniting for Peace, the Assembly can do so only within the limited context of supporting the exercise by States of their inherent right to individual or collective self-defense under Article 51 of the Charter. Otherwise, for the Assembly to recommend the use of coercive force would be of dubious legal validity and States who followed such a recommendation would risk violating Article 2 (4) of the Charter and thus being held internationally responsible for having committed an internationally wrongful act.

That is not to say that the Assembly cannot make recommendations for collective measures with regard to any given situation or dispute which threatens international peace and security - far from it. It is simply to recognize that the Organization and how its Charter is applied has evolved since 1950. The Uniting for Peace procedures and terms may provide "inspiration," but they need not be invoked or followed in order for the Assembly to make recommendations regarding collective measures short of coercive force. The Assembly may even make recommendations within the context of the exercise of individual or collective self-defense but should stay clear of making recommendations in the area which remains within the exclusive domain of the Council: imposing explicit obligations of compliance and requiring or authorizing coercive enforcement action by the use of force. Rather than the seemingly constant reference to the Assembly using force under Uniting for Peace, what is needed is more thought given to innovative and inventive non-use of force measures which the Assembly could employ in situations where the Council has been blocked by a veto. 